\title{
Assessing the role of submarine groundwater discharge as a source of Sr to the Mediterranean Sea
}

\author{
Giada Trezzi ${ }^{* 1}$, Jordi Garcia-Orellana ${ }^{1,2}$, Valentí Rodellas $^{1,3}$, Pere Masqué ${ }^{1,2,4,5}$ \\ Ester Garcia-Solsona ${ }^{6}$, Per S Andersson ${ }^{7}$.
}

${ }^{1}$ Institut de Ciència i Tecnologia Ambientals, Universitat Autònoma de Barcelona, 08193 Bellaterra, Catalunya, Spain

${ }^{2}$ Departament de Física, Universitat Autònoma de Barcelona, 08193 Bellaterra, Catalunya, Spain ${ }^{3}$ CEREGE, Aix-Marseille Université, 13545 Aix-en-Provence, France

${ }^{4}$ School of Natural Sciences and Centre for Marine Ecosystems Research, Edith Cowan University, 270 Joondalup Drive, Joondalup WA 6027, Australia

${ }^{5}$ Oceans Institute and School of Physics, The University of Western Australia, 35 Stirling Highway, Crawley, WA 6009, Australia

${ }^{6}$ Departament de Dinàmica de la Terra i de l'Oceà, Universitat de Barcelona, C/Martí i Franqués, 08028 Barcelona, Catalunya, Spain

${ }^{7}$ Department of Geosciences, Swedish Museum of Natural History, 104 05, Stockholm, Sweden

*Corresponding authors: Giada Trezzi

Giada.Trezzi@uab.cat; giada.trezzi@gmail.com

Jordi Garcia-Orellana

Jordi.Garcia@uab.cat 


\section{Abstract}

Submarine groundwater discharge (SGD) has been identified as an important source of Sr to the ocean and the SGD-driven Sr flux to the global ocean has been recently re-evaluated (Beck et al. 2013). However, the uncertainty of this value is still high because of the uncertainties related to the determination of SGD flow rates and the paucity of ${ }^{87} \mathrm{Sr} /{ }^{86} \mathrm{Sr}$ data in SGD end-members. As carbonates have high $\mathrm{Sr}$ concentrations and are subjected to intense heightened weathering, they might significantly influence the SGD input of $\mathrm{Sr}$ to the ocean. Here we present data on $\mathrm{Sr}$ concentrations and ${ }^{87} \mathrm{Sr} /{ }^{86} \mathrm{Sr}$ ratios in three carbonate dominated sites of the western area of the Mediterranean Sea, a semi-enclosed basin characterized by abundant coastal carbonates. The ${ }^{87} \mathrm{Sr} /{ }^{86} \mathrm{Sr}$ ratios in groundwater were lower compared to modern seawater $(\sim 0.70916)$, as expected for areas dominated by carbonate lithologies. Concentrations of $\mathrm{Sr}$ and ${ }^{87} \mathrm{Sr} /{ }^{86} \mathrm{Sr}$ ratios in groundwater showed conservative mixing in the studied subterranean estuaries. By using SGD flow rates reported in the literature for the study areas, a meteoric SGD-driven Sr flux of $(0.12-2.1) \cdot 10^{3} \mathrm{~mol} \mathrm{~d}^{-1} \mathrm{~km}^{-1}$ was calculated for the region, with a fresh SGD end-member characterized by a $\mathrm{Sr}$ concentration of $27-30 \mu \mathrm{M}$ and $\mathrm{a}^{87} \mathrm{Sr} /{ }^{86} \mathrm{Sr}$ ratio of $0.708020-0.707834$.

Integrating these $\mathrm{Sr}$ data with literature data (i.e. values of $\mathrm{Sr}$ concentration and ${ }^{87} \mathrm{Sr} /{ }^{86} \mathrm{Sr}$ ratio from other lithologies as well as SGD flow rates), we also calculated the fresh SGD-driven Sr flux to the entire Mediterranean Sea, obtaining a value of ( $0.34-$ $0.83) \cdot 10^{9} \mathrm{~mol} \mathrm{y}{ }^{-1}$, with a ${ }^{87} \mathrm{Sr} /{ }^{86} \mathrm{Sr}$ of $0.7086-0.7081$. Thus, for the entire Mediterranean basin, SGD is globally a source of Sr less radiogenic compared to seawater. The SGD Sr flux to the Mediterranean Sea represents 5-6\% of the SGD Sr flux to the global ocean and the Mediterranean SGD end-member has higher $\mathrm{Sr}$ 
concentration $(5.0-12 \mu \mathrm{M})$ than the global SGD end-member $(2.9 \mu \mathrm{M})$. This confirms the significant role of carbonate lithologies on SGD-driven Sr fluxes to seawater. The fresh SGD-driven Sr flux to the Mediterranean Sea is about $20-50 \%$ of the riverine Sr input and significantly higher than the input through atmospheric dust deposition. Therefore SGD should be considered as an important continental source of Sr to the basin. 


\section{Introduction}

The ${ }^{87} \mathrm{Sr} /{ }^{86} \mathrm{Sr}$ ratio in marine carbonates reflects the composition of seawater at the time of the carbonate deposition and thus can be used as a tool for studies on paleoclimatic reconstructions and stratigraphic correlations (Burke et al. 1982). The residence time of $\mathrm{Sr}$ in seawater $(>2.5 \mathrm{My})$ is much longer than the time of ocean mixing ( $1500 \mathrm{y}$ ), so that the ${ }^{87} \mathrm{Sr} /{ }^{86} \mathrm{Sr}$ ratio is homogeneous in seawater with a salinity of about 35, with a current value of $\sim 0.70916$ (Broecker and Peng 1982; Beck et al. 2013), but with large variation over geological time scale (Burke et al. 1982).

However, the ${ }^{87} \mathrm{Sr} /{ }^{86} \mathrm{Sr}$ ratio can be different in seawater with lower salinity in marginal and coastal seas (Andersson et al. 1992; Huang et al. 2011).

The ${ }^{87} \mathrm{Sr} /{ }^{86} \mathrm{Sr}$ ratio of seawater is related to the isotope composition of the Sr inputs, including mainly rivers, hydrothermal systems, seafloor sediments and submarine groundwater discharge (SGD) (e.g. Albarède et al., 1981; Allègre et al., 2010; Beck et al., 2013; Davis et al., 2003; Martin and Moore, 2008; Palmer and Edmond, 1989). The different $\mathrm{Sr}$ isotope compositions of these sources of $\mathrm{Sr}$ reflect the $\mathrm{Rb} / \mathrm{Sr}$ ratio of the minerals of the rocks interacting with the water. Generally, rocks composed of K-rich minerals (intrusive, metamorphic and siliciclastic sedimentary rocks) have higher ${ }^{87} \mathrm{Sr} /{ }^{86} \mathrm{Sr}$, as ${ }^{87} \mathrm{Sr}$ is produced from the decay of ${ }^{87} \mathrm{Rb}\left(\mathrm{t}_{1 / 2}=4.9 \cdot 10^{10} \mathrm{y}\right)$, which can substitute $\mathrm{K}$ in minerals. In contrast, rocks largely composed of Ca-rich minerals (carbonates, evaporites and volcanic rocks) have lower ${ }^{87} \mathrm{Sr} /{ }^{86} \mathrm{Sr}$, primarily due to a lower $\mathrm{Rb} / \mathrm{Sr}$ ratio; these rocks are enriched in $\mathrm{Sr}$, as $\mathrm{Sr}$ can substitute $\mathrm{Ca}$ in minerals (McNutt 2000). 
Early calculations of the marine $\mathrm{Sr}$ isotope budget considering only rivers, hydrothermal systems and diagenesis of seafloor sediments, yield a significant imbalance, mainly because the worldwide fluvial transport of more radiogenic $\mathrm{Sr}$ exceeded the contribution of less radiogenic Sr from the other sources (Albarède et al. 1981; Palmer and Edmond 1989; Davis et al. 2003). The significance of SGD inputs of Sr has been evaluated only in recent years (Basu et al. 2001; Allègre et al. 2010; Rahaman and Singh 2012; Beck et al. 2013). SGD is the combination of meteoric groundwater and recirculated seawater, discharging into the coastal sea through coastal aquifers (Moore 1996; Burnett et al. 2003). This process is a significant source of chemical compounds (e.g, macronutrients, trace metals, carbon, REEs) to the coastal ocean (e.g. Cai et al. 2003; Slomp and Van Cappellen 2004; Windom et al. 2006; Johannesson et al. 2011). Beck et al. (2013) conducted the first calculation of the SGD contribution on the marine Sr isotope budget, concluding that SGD (fresh and brackish components) accounts for $13-31 \%$ of this budget and represents generally a source of $\mathrm{Sr}$ less radiogenic than modern seawater. This reduces the imbalance of the marine $\mathrm{Sr}$ isotope budget in the ocean.

Despite the significant improvements in estimating the marine $\mathrm{Sr}$ isotope budget, the uncertainty of the SGD-driven Sr flux is still large. This is primarily due to the uncertainties associated with the volumetric discharge of groundwater and the paucity of ${ }^{87} \mathrm{Sr} /{ }^{86} \mathrm{Sr}$ data in SGD. In particular, new data on carbonate SGD end-members may be essential to refine the global SGD estimation, as carbonates have major effects on SGD fluxes, being characterized by a high Sr concentration and alteration grade (Beck et al. 2013). 
The Mediterranean Sea is an interesting site for the study of SGD-driven Sr fluxes primarily due to: i) the wide areas of carbonate bedrock in the drainage basin (Amiotte Suchet et al. 2003; Dürr et al. 2005); ii) the magnitude of SGD flow rates (Rodellas et al. 2015); iii) the significance of SGD as source of chemical compounds to this basin (e.g. Tovar-Sánchez et al., 2014; Rodellas et al., 2015; Trezzi et al., 2016a; Trezzi et al., 2016b).

In this work, we investigate the SGD-driven Sr fluxes in three different carbonatedominant coastal areas in the Western Mediterranean Sea: the Irta Range, the Peníscola wetland and the Ebro Delta. The focus is primarily on the eastern coast of the Iberian Peninsula, where SGD fluxes have been quantified recently (Garcia-Solsona et al. 2010; Mejías et al. 2012; Rodellas et al. 2012, 2017) and the hydrogeological sites are wellknown. We also attempt to estimate the SGD-driven Sr flux to the entire Mediterranean Sea and to compare it to the other sources of Sr to the basin.

\section{Methodology}

\subsection{Area of study}

The Mediterranean Sea is a semi-enclosed marginal basin that covers a surface of about $2.5 \cdot 10^{6} \mathrm{~km}^{2}$. It is connected to the Atlantic Ocean through the Strait of Gibraltar, with a width of $14 \mathrm{~km}$ at its narrowest point and a minimum depth of $290 \mathrm{~m}$ (SotoNavarro et al. 2010). The inflow of Atlantic water into the Mediterranean Sea through the Strait of Gibraltar is around $26 \cdot 10^{12} \mathrm{~m}^{3} \mathrm{y}^{-1}$ and exceeds the outflow of 
Mediterranean waters, which is around $25 \cdot 10^{12} \mathrm{~m}^{3} \mathrm{y}^{-1}$ (Soto-Navarro et al. 2010).

Evaporation in the Mediterranean Sea is higher than freshwater inputs and this difference exceeds the net inflow of oceanic waters, so that the salinity of the Mediterranean Sea is higher than the salinity of the global oceans (Flecker et al. 2002).

The Mediterranean Sea is characterized by a drainage basin with predominant sedimentary bedrock (Peucker-Ehrenbrink et al. 2010). Carbonate rocks occupy up to $20 \%$ of the drainage basin, dominating in particular the northern catchment (Mesozoic carbonates) (Dürr et al. 2005; Topper et al. 2011). In relative terms, the area covered by carbonates is about two times larger than the area occupied by carbonates in the global ocean drainage basin. Riverine discharge to the basin is currently around $0.3 \cdot 10^{12} \mathrm{~m}^{3} \mathrm{y}^{-1}$ (Ludwig et al. 2009). Total SGD flow rate to the Mediterranean Sea ranges from $0.3 \cdot 10^{12}$ to $4.8 \cdot 10^{12} \mathrm{~m}^{3} \mathrm{y}^{-1}$ (Rodellas et al. 2015), while the flow rate of fresh groundwater is about $0.07 \cdot 10^{12} \mathrm{~m}^{3} \mathrm{y}^{-1}$ (Zektser et al. 2007).

The eastern coast of the Iberian Peninsula is located in the Western Mediterranean Sea and is characterized by outcrops of Mesozoic carbonate rocks (Instituto Geologico Minero de España (IGME) 1986). In this area, SGD flow rates to the sea have been quantified in several coastal locations in recent years (Garcia-Solsona et al. 2010; Mejías et al. 2012; Rodellas et al. 2012, 2017). The riverine discharge along the eastern coast of the Iberian Peninsula is dominated by the Ebro River, which is the $4^{\text {th }}$ largest river discharging into the Mediterranean Sea in terms of flow rate $\left(13 \cdot 10^{9} \mathrm{~m}^{3} \mathrm{y}^{-1}\right)$ (Ludwig et al. 2009). 
In this work, we investigated in particular three locations, characterized by different common coastal environments of the Mediterranean area: the Irta Range area, the Peníscola wetland and the Ebro Delta area (Figure 1a).

Irta Range. The area is characterized by the presence of a coastal chain formed by Mesozoic carbonates subjected to karstification processes (Mejías et al. 2008). Brackish coastal springs have been identified along the shoreline in relation with karstified pathways for groundwater. The estimated SGD flow rate from the main coastal springs of the Irta Range is of $(72-190) \cdot 10^{3} \mathrm{~m}^{3} \mathrm{~d}^{-1}$ and it depends on the period of the year (Garcia-Solsona et al. 2010).

Peníscola wetland. The area is characterized by a shallow brackish-water marsh, located just north of the Irta Range. The marsh is artificially connected to the Mediterranean Sea through three channels converging into a single channel at the end of the wetland. It is fed mainly by shallow groundwater flows from the detrital aquifer, composed by porous material, and the local karstic aquifers (Vinarós-Peníscola and Irta Range, respectively) (>80\%) and deep groundwater ( 15\%) from the El Maestrat regional carbonate aquifer, while the contribution from seawater is small $(<5 \%)$ (Rodellas et al. 2012; Zarroca et al. 2014). Measured groundwater discharge flow rates through the artificial marsh outlet are in the range of $(34-83) \cdot 10^{3} \mathrm{~m}^{3} \mathrm{~d}^{-1}$ (Rodellas et al. 2012).

Ebro Delta. The Ebro Delta area is characterized by the presence of the Alfacs and El Fangar Bays, which are semi-enclosed bays, partially isolated from the Mediterranean Sea through a sandy barrier (Camp and Delgado 1987). The Alfacs Bay receives freshwater mainly from irrigation channels for rice fields located in the delta and groundwater from the carbonate Montsià Range (Bayó et al. 1993; Llebot et al. 2014). The irrigation channels connect the bay to the Ebro River, as well as to 
groundwater accumulated in shallow ponds from large springs locally denominated "ullals" (Bayó et al. 1993). Estimated SGD flow rates to the bay from the Montsià Range coastal aquifer vary seasonally in the range of $(40-310) \cdot 10^{3} \mathrm{~m}^{3} \mathrm{~d}^{-1}$ (Rodellas et al. 2017).

\subsection{Sample collection}

In total six surveys were conducted to collect groundwater samples between December 2012 and November 2013. In the Irta Range area (Figure 1b), 3 coastal karstic springs (KS1, KS2, KS3) directly discharging into the sea were sampled and groundwater was also collected from a well located at the northern boundary of the Irta Range (W1), next to the sea. In the Peníscola wetland (Figure 1c), five groundwater samples (S1LL; S1C; S2LL; S2C; S3) were collected from piezometers at different depths $(60,25,16,12$ and $4 \mathrm{~m}$, respectively). Shallow groundwater of the detrital aquifer was collected from a channel in the northern part of the wetland (ST7). Two groundwater samples were collected from two large ponds (tens of meters in diameter) nourished by submerged springs (P1; P2). A channel characterized by a submerged spring (ST32) was sampled at three different water column depths: bottom depth (0.9 $\mathrm{m})$, intermediate depth (0.4 m) and surface (ST32D, ST32M and ST32S, respectively). Groundwater from a deep well (W2) located at the west of the marsh, was collected. The outlet connecting marsh groundwater to the coastal sea (ST47) was also sampled, as well as seawater near the dock of Peníscola village (SW1). In the Ebro Delta area (Figure 1d), two coastal karstic springs (KS4, KS5) directly discharging into the sea and four irrigation channels connected to the sea $(\mathrm{C} 1, \mathrm{C} 2, \mathrm{C} 3$ and $\mathrm{C} 4)$ were sampled. Groundwater was also collected from a well (W3) and from a shallow pond (P3), next 
to the irrigation channels. Samples from the Ebro River (ER) and from the central part of the bay (SW2) were also collected. Three seawater samples collected during the Geotraces-GA04 - MedSea cruise $\left(2^{\text {nd }}\right.$ May - $2^{\text {nd }}$ June 2013) were included in our data set (Figure 1a): i) surface seawater of the Catalano-Balearic basin, at $105 \mathrm{~km}$ offshore from Barcelona (SW3), representative of the general Mediterranean seawater endmember; ii) surface seawater at the Gibraltar Strait (SW4), representative of the Atlantic inflow into the Mediterranean Sea; iii) 500 m-depth seawater at the Gibraltar Strait (SW5), representative of the Mediterranean outflow.

For each sample, $125 \mathrm{~mL}$ of unfiltered water were collected following trace metal clean techniques (Tovar-Sánchez 2012) and stored in acid-cleaned plastic bottles. Samples were acidified to $\mathrm{pH}<2$ with trace-metal grade $\mathrm{HCl}$ or $\mathrm{HNO}_{3}$. At each sampling point, salinity was measured with a calibrated YSI 556 handheld probe. Samples SW3, SW4 and SW5 were collected with a Niskin bottle and acidified to $\mathrm{pH}<2$ with tracemetal grade $\mathrm{HNO}_{3}$.

\subsection{Analysis}

Sr concentrations $\left(\mathrm{C}_{\mathrm{Sr}}\right)$ and ${ }^{87} \mathrm{Sr} /{ }^{86} \mathrm{Sr}$ ratios in water samples were determined using thermal ionization mass spectrometry (TIMS). Between 0.2 and $2 \mathrm{~mL}$ of water were used for the analysis, depending on the $\mathrm{C}_{\mathrm{Sr}}$ in the sample. An enriched ${ }^{84} \mathrm{Sr}$ spike was added to each sample, which was then passed through an ion-exchange resin following the method described in Delmonte et al. (2008). About $400 \mathrm{ng}$ of purified Sr mixed with a Ta activator was load on a single Re filament and analysed in a Thermo Scientific TRITON TIMS. Two hundred 8-second integrations were recorded in multi-collector 
static mode, applying rotating gain compensation. Measured ${ }^{87} \mathrm{Sr}$ intensities were corrected for $\mathrm{Rb}$ interference using ${ }^{87} \mathrm{Rb} /{ }^{85} \mathrm{Rb}=0.38600$ and ratios were reduced using the exponential fractionation law and ${ }^{88} \mathrm{Sr} /{ }^{86} \mathrm{Sr}=8.375209$. Repeated measurements of prepared CIT \#39 seawater provided a reproducibility of $\pm 0.0000082(\mathrm{n}=21)$, which was used as the uncertainty of the ${ }^{87} \mathrm{Sr} /{ }^{86} \mathrm{Sr}$ measurements. The NBS 987 standard was also measured regularly, with a reproducibility of $\pm 0.000015(\mathrm{n}=12)$. The ${ }^{87} \mathrm{Sr} /{ }^{86} \mathrm{Sr}$ ratio for the NBS 987 standard was $0.710217 \pm 0.000016(\mathrm{n}=5) .{ }^{87} \mathrm{Sr} /{ }^{86} \mathrm{Sr}$ reported in this work for the analysed samples are normalized to a value for NBS 987 of 0.710245 (Haley et al. 2008). The external precision of the $\mathrm{C}_{\mathrm{Sr}}$ measured in the CIT \#39 seawater was estimated to be about $0.5 \%$. The total procedural blank for $\mathrm{Sr}$ was $<20 \mathrm{pg}$, which is several orders of magnitude lower than the $\mathrm{C}_{\mathrm{Sr}}$ measured in the samples, so that no blank correction was necessary.

\section{Results}

Salinity, $\mathrm{C}_{\mathrm{Sr}}$ and ${ }^{87} \mathrm{Sr} /{ }^{86} \mathrm{Sr}$ ratios for all samples are summarized in Table 1 . The three seawater samples collected during the Geotraces-GA04 - MedSea cruise showed ${ }^{87} \mathrm{Sr} /{ }^{86} \mathrm{Sr}$ ratios in agreement with the typical ocean ${ }^{87} \mathrm{Sr} /{ }^{86} \mathrm{Sr}$ ratio of $\sim 0.70916$ (Broecker and Peng 1982; Beck et al. 2013). On the contrary, salinities and $\mathrm{C}_{\mathrm{Sr}}$ showed some difference: the surface seawater of the Catalano-Balearic Sea (SW3) had a salinity of 38.3 and a $\mathrm{C}_{\mathrm{Sr}}$ of $95 \mu \mathrm{M}$; the surface seawater of the Gibraltar Strait, representing the Atlantic inflow (SW4), had the lowest salinity and $\mathrm{C}_{\mathrm{Sr}}(36.3$ and $90 \mu \mathrm{M}$, respectively); the 500 m-depth seawater of the Gibraltar Strait (Mediterranean outflow) had the highest salinity and $\mathrm{C}_{\mathrm{Sr}}(38.5$ and $96 \mu \mathrm{M}$, respectively). Compared to surface seawater 
SW3, seawater samples collected at Peníscola (SW1) and in the Ebro Delta area (SW2) had lower salinity (37.1 and 34.9, respectively), lower $\mathrm{C}_{\mathrm{Sr}}(92 \mu \mathrm{M}$ and $89 \mu \mathrm{M}$, respectively) and comparable ${ }^{87} \mathrm{Sr} /{ }^{86} \mathrm{Sr}$ ratio (0.709158). Figure 2 showed the conservative behaviour of $\mathrm{C}_{\mathrm{Sr}}$ in all the seawater samples analysed, excepting sample SW2, which plotted above the linear relationship between salinity and $\mathrm{C}_{\mathrm{Sr}}$. The deviation of seawater SW2 from this linear trend indicated that it is possible to detect deviations of Sr from conservative mixing at high salinity. Indeed, sample SW2, which is located in a semi-enclosed bay, could be influenced by the inputs of Sr through SGD, the irrigation channels or the Ebro River characterizing the Ebro Delta area.

In the Irta Range area, coastal karstic springs had salinities ranging from 5.8 to 8.7, $\mathrm{C}_{\mathrm{Sr}}$ from 19 to $28 \mu \mathrm{M}$ (average: $24 \pm 5 \mu \mathrm{M}$ ) and ${ }^{87} \mathrm{Sr} /{ }^{86} \mathrm{Sr}$ ratios from 0.708904 to 0.708981 (average: $0.708946 \pm 0.000039$ ). The groundwater sample W1, which was the fresh groundwater end-member, had a salinity of 0.3 , a $\mathrm{C}_{\mathrm{Sr}}$ of $6.0 \mu \mathrm{M}$ and a ${ }^{87} \mathrm{Sr} /{ }^{86} \mathrm{Sr}$ ratio of 0.707810 . Taking the surface seawater sample from the Catalano-Balearic Sea (SW3) as the seawater end-member, the groundwater of the karstic springs showed a conservative behaviour of $\mathrm{C}_{\mathrm{Sr}}$ and $\mathrm{Sr}$ isotope ratios throughout the mixing between groundwater and seawater (Figure 3).

In the Peníscola wetland, $\mathrm{C}_{\mathrm{Sr}}$ and $\mathrm{Sr}$ isotope ratios showed conservative mixing patterns (Figure 4). Salinities of groundwater samples ranged from 0.3 to $20.3, \mathrm{C}_{\mathrm{Sr}}$ ranged between 6.0 and $170 \mu \mathrm{M}$ and ${ }^{87} \mathrm{Sr} /{ }^{86} \mathrm{Sr}$ ratios ranged from 0.707810 to 0.708473 . Sr data for the Peníscola wetland confirmed the results obtained by Rodellas et al. (2012) and Zarroca et al. (2014) (Figure 4): groundwater accumulated in the wetland was the result of mixing between deep groundwater from the regional carbonate aquifer 
(S1LL) and shallow groundwater from the detrital aquifer (ST7) and/or the local karstic aquifer (sample W1, collected at the northern boundary of the Irta Range). On the contrary, the contribution from seawater to the wetland was not significant.

Groundwater collected from well W2 likely represented a mixing between detrital aquifer (ST7) and local karstic aquifer (W1) end-members. Water collected from the outlet connecting the marsh with the coastal sea (ST47) had a salinity of 5.3, a $\mathrm{C}_{\mathrm{Sr}}$ of 46 $\mu \mathrm{M}$ and $\mathrm{a}^{87} \mathrm{Sr} /{ }^{86} \mathrm{Sr}$ of 0.708388 . This sample was a natural average of waters in the Peníscola wetland and can be used to characterize groundwater discharging into the sea from this studied area (i.e. it can be used as the SGD end-member).

In the Ebro Delta area, groundwater collected from two karstic springs (KS4 and KS5) had salinities of 5.8 and $4.2, \mathrm{C}_{\mathrm{Sr}}$ of 44 and $47 \mu \mathrm{M}$ (average: $45.6 \pm 2.4 \mu \mathrm{M}$ ) and ${ }^{87} \mathrm{Sr} /{ }^{86} \mathrm{Sr}$ ratios of 0.708108 and 0.707949 (average: $0.708029 \pm 0.000112$ ).

Groundwater from the well W3 and from the shallow pond P3 had salinities of 2.2 and $1.2, \mathrm{C}_{\mathrm{Sr}}$ of $30 \mu \mathrm{M}$ and $12 \mu \mathrm{M}$ and ${ }^{87} \mathrm{Sr} /{ }^{86} \mathrm{Sr}$ ratios of 0.707923 and 0.708068 , respectively. Water samples collected from the irrigation channels had salinities ranging from 0.9 to $31.2, \mathrm{C}_{\mathrm{Sr}}$ ranging from 18 to $70 \mu \mathrm{M}$ and ${ }^{87} \mathrm{Sr} /{ }^{86} \mathrm{Sr}$ ratios between 0.708116 and 0.709090 . The sample of the Ebro River had a salinity of $0.7, \mathrm{C}_{\mathrm{Sr}}$ of $22 \mu \mathrm{M}$ and a ${ }^{87} \mathrm{Sr} /{ }^{86} \mathrm{Sr}$ ratio of 0.708547 . The $\mathrm{Sr}$ concentrations and the $\mathrm{Sr}$ isotope ratios measured in the Ebro Delta area showed conservative mixing behaviour (Figure 5). This was evident in the irrigation channels ( $\mathrm{C} 1$ and $\mathrm{C} 2)$, both for the mixing line between the Ebro River (ER) and seawater (SW3) and for the mixing line between the Ebro River (ER) and the shallow pond nourished with groundwater (P3). On the contrary, for the irrigation channel $\mathrm{C} 3$, the $\mathrm{C}_{\mathrm{Sr}}$ plotted below the conservative mixing line between the Ebro River (ER) and seawater (Figure 5a), indicating possible removal of $\mathrm{Sr}$ from the solution or 
contribution from another source, while the ${ }^{87} \mathrm{Sr} /{ }^{86} \mathrm{Sr}$ follow the conservative mixing trend (Figure 5b). It was not possible to establish whether $\mathrm{Sr}$ from groundwater in the karstic springs KS4 and KS5 mixed conservatively with seawater or not, as the fresh groundwater end-member of the system was not collected (Figure 5). Water from the irrigation channel $\mathrm{C} 4$ and from the well $\mathrm{W} 3$ did not follow the two end-member mixing lines plotted in Figure 5, indicating a mixing between a higher number of end-members.

\section{Discussion}

\subsection{Sr in the subterranean estuary}

The $\mathrm{C}_{\mathrm{Sr}}$ and the ${ }^{87} \mathrm{Sr} /{ }^{86} \mathrm{Sr}$ ratios show that $\mathrm{Sr}$ mixes conservatively in the investigated subterranean estuaries. This conservative mixing cannot be confirmed for the karstic springs of the Ebro Delta area, primarily because the fresh groundwater endmember of the system was not collected. However, the similarity of this hydrogeological context (groundwater flowing from a coastal karstic chain discharging into the sea through coastal brackish springs) with the Irta Range area, suggests that $\mathrm{Sr}$ would also mix conservatively in this subterranean estuary.

The conservative $\mathrm{C}_{\mathrm{Sr}}$-salinity mixing are consistent with previous studies conducted in other subterranean estuaries (Rahaman and Singh 2012; Beck et al. 2013). The Sr concentrations in deep groundwater and in a submerged spring (ST32D) of the Peníscola wetland were higher compared to seawater. This is probably due to the dissolution of the evaporate-rich Keuper unit at the basement of the deep regional carbonate aquifer (Zarroca et al. 2014). This Sr-enriched groundwater showed 
conservative mixing in the wetland. The Keuper unit is also probably the source of the high salinity (20.3) in the deep groundwater end-member of the wetland (S1LL).

Unlike $\mathrm{Sr}$ concentrations, the conservative $\mathrm{Sr}$ isotope ratio patterns in the studied subterranean estuaries are in contrast to observations from other locations, where non conservative ${ }^{87} \mathrm{Sr} /{ }^{86} \mathrm{Sr}$ trends in subterranean estuaries, associated with conservative $\mathrm{Sr}$ concentrations trends, were highlighted and attributed to isotope exchange between dissolved $\mathrm{Sr}$ in seawater and Sr adsorbed on aquifer solids (Beck et al. 2013). This twoway flux of Sr between solid and fluid phases has also been documented in the mixing between river water and seawater, in particular in the presence of volcanic riverine particulate material (Jones et al. 2012, 2014). The conservative mixing behaviour of $\mathrm{Sr}$ isotopes in the studied subterranean estuaries indicates minor impact of desorption/adsorption of $\mathrm{Sr}$ from/on the aquifer solids throughout the mixing of fresh and salty waters.

Despite the results on Sr isotopes obtained in the studied subterranean estuaries, it is not possible to determine an unequivocal behaviour of Sr isotopes in subterranean estuaries in carbonate terrains. Indeed, the trends of ${ }^{87} \mathrm{Sr} /{ }^{86} \mathrm{Sr}$ in different subterranean estuaries in carbonate sites may be different, as observed when comparing results from this work and data reported by Beck et al. (2013) on the Yucatan Peninsula and on Florida, which are characterized by carbonate lithologies.

\subsection{SGD-driven Sr fluxes from the eastern coast of the Iberian Peninsula}

Data on $\mathrm{C}_{\mathrm{Sr}}$ measured in this work can be used to quantify SGD-driven $\mathrm{Sr}$ fluxes to the sea by multiplying $\mathrm{C}_{\mathrm{Sr}}$ of groundwater samples by the SGD flow rates reported in the literature (Table 2). 
In the Irta Range area, SGD flow rates of $72-190 \cdot 10^{3} \mathrm{~m}^{3} \mathrm{~d}^{-1}$ have been reported (Garcia-Solsona et al. 2010). Taking into account the average $\mathrm{C}_{\mathrm{Sr}}$ measured in the three karstic samples KS1, KS2 and KS3, Sr fluxes are in the range of $(1.7-4.4) \cdot 10^{3} \mathrm{~mol} \mathrm{~d}^{-1}$. In the Peníscola marsh area, SGD flow rates of $(34-83) \cdot 10^{3} \mathrm{~m}^{3} \mathrm{~d}^{-1}$ have been measured in the channel connecting the wetland to the sea (Rodellas et al. 2012). Considering the $\mathrm{C}_{\mathrm{Sr}}$ of ST47, an SGD-driven Sr flux of $(1.6-3.9) \cdot 10^{3} \mathrm{~mol} \mathrm{~d}^{-1}$ is obtained. For the Ebro Delta area, the SGD flow rate from the Montsià Range is $(40-310) \cdot 10^{3} \mathrm{~m}^{3} \mathrm{~d}^{-1}$ (Rodellas et al. 2017). Considering the average $\mathrm{C}_{\mathrm{Sr}}$ of the two karstic springs KS4 and KS5 sampled in this work, Sr fluxes of $(1.8-14) \cdot 10^{3} \mathrm{~mol} \mathrm{~d}^{-1}$ are obtained. The SGD-driven Sr fluxes calculated for the Irta Range and Ebro Delta study areas include both the fresh groundwater and the recirculated seawater components of SGD. Since the $\mathrm{C}_{\mathrm{Sr}}$ is generally higher in seawater compared to groundwater and Sr mixes conservatively, a portion of the $\mathrm{Sr}$ measured in the brackish mixture is derived from the seawater itself. Assuming that the recirculation of seawater through the subterranean estuary do not represent a net source of Sr to the sea, the flux of Sr should be calculated only considering fresh groundwater end-members. The fresh groundwater flow rate in the Irta Range area is $(51-160) \cdot 10^{3} \mathrm{~m}^{3} \mathrm{~d}^{-1}$ (Garcia-Solsona et al. 2010). For the Ebro Delta area, we calculated the fresh groundwater flow rate considering the brackish flows and the average salinity of the springs, obtaining a value of $(35-270) \cdot 10^{3} \mathrm{~m}^{3} \mathrm{~d}^{-1}$. Water collected from well W1 is considered as the fresh groundwater end-member in the Irta Range system. For the Ebro Delta area, fresh groundwater was not collected, but the $\mathrm{C}_{\mathrm{Sr}}$ of the fresh groundwater end-member can be calculated by extrapolating the Sr mixing line between the brackish springs and seawater SW3 to a salinity of zero (Figure 5a), obtaining a value of $38.2 \pm 0.2 \mu \mathrm{M}$. Using this value of $\mathrm{C}_{\mathrm{Sr}}$, the ${ }^{87} \mathrm{Sr} /{ }^{86} \mathrm{Sr}$ ratio of this fresh groundwater end-member can be calculated from the mixing line between the 
brackish springs and seawater SW3 in Figure 5b, obtaining a value of $0.707630 \pm$ 0.000028 . Fresh SGD Sr fluxes to the coastal sea are $(0.31-0.96) \cdot 10^{3}$ and $(1.3-10) \cdot 10^{3}$ $\mathrm{mol} \mathrm{d}^{-1}$ for the Irta Range and Ebro Delta areas, respectively.

In the case of the Peníscola wetland, it is not possible to calculate fresh SGD fluxes to the sea considering the salinity of the SGD end-members, as the groundwater end-member discharging into the sea is a mixing of fresh groundwater from the local detrital aquifer (ST7) and salty groundwater from the deep regional carbonate aquifer (see Section 4.1). However, as shown in Figure 4a and 4b, water flowing into the sea from the wetland is not particularly affected by seawater and thus the recirculation of seawater in the subterranean estuary is minimal or absent. Therefore, the brackish $\mathrm{Sr}$ water flux calculated above for the channel connecting the marsh to the sea can be considered a first approximation of the net $\mathrm{Sr}$ flux to the coastal sea.

From the fresh SGD end-members of the Irta Range and the Ebro Delta areas and the water of the outlet of the Peníscola wetland (ST47), we calculate a flow-weighted average $\mathrm{C}_{\mathrm{Sr}}$ and $\mathrm{Sr}$ isotope ratio, representative of the carbonate SGD end-member of the eastern coast of the Iberian Peninsula. Considering minimum and maximum fresh SGD flow rates of the study areas, ranges of $27-30 \mu \mathrm{M}$ and $0.708020-0.707834$ are obtained for the $\mathrm{C}_{\mathrm{Sr}}$ and the $\mathrm{Sr}$ isotope ratio, respectively. In accordance with the dominant carbonate lithology of the region, the flow-weighted ${ }^{87} \mathrm{Sr} /{ }^{86} \mathrm{Sr}$ ratio of the SGD end-member is thus lower than in modern seawater, so that SGD is an input of less radiogenic $\mathrm{Sr}$ in this area of the Mediterranean Sea. The ranges in $\mathrm{C}_{\mathrm{Sr}}$ and $\mathrm{Sr}$ isotope ratios representative of the fresh SGD end-member can be compared with those of the Ebro River, the most important river in the region in terms of flow rate $\left(36 \cdot 10^{6} \mathrm{~m}^{3} \mathrm{~d}^{-1}\right)$ (Ludwig et al. 2009). The $\mathrm{C}_{\mathrm{Sr}}$ of the Ebro River at a salinity of 0.7 is $22 \mu \mathrm{M}$, which is 
lower than the flow-weighted average $\mathrm{C}_{\mathrm{Sr}}$ of the fresh SGD end-members by a factor of 1.2 - 1.4. The ${ }^{87} \mathrm{Sr} /{ }^{86} \mathrm{Sr}$ ratio of the Ebro River is 0.708547 and thus is higher than that of the SGD typical of the region, although it is lower than in modern seawater. Despite the lower $\mathrm{C}_{\mathrm{Sr}}$ in the Ebro River with respect to the fresh SGD end-member, the Sr flux from this source is $800 \cdot 10^{3} \mathrm{~mol} \mathrm{~d}^{-1}$, which is at least four orders of magnitude higher than the SGD-driven Sr fluxes calculated for each study area.

\subsection{SGD-driven Sr flux to the Mediterranean Sea}

As $\mathrm{Sr}$ is generally more enriched in seawater compared to groundwater and it mixes conservatively in the subterranean estuaries, an approximation of the SGD-driven net $\mathrm{Sr}$ flux to the Mediterranean Sea could be obtained considering the fresh component of SGD.

We apply a simple model based on the combination of fresh SGD flow rates and Sr composition (concentration and isotope ratio) typical of groundwater from different types of aquifers in order to calculate the meteoric SGD Sr flux to the entire Mediterranean Sea. We use the volumetric discharges of meteoric groundwater obtained from regional hydrogeological assessments (Zektser et al., 2007), while the global lithological database GLIM (Hartmann and Moosdorf 2012) is used for the classification of the different types of aquifers and the evaluation of their relative percentages in the coastal areas of the Mediterranean Sea. This global lithological map presents 13 different primary categories of dominant lithologies, which have been assembled in 5 different groups of types of aquifers in this work, on the base of geological origin and/or predominant minerals (Table 3): carbonate, siliciclastic, granite, volcanic and complex groups. The most significant coastal lithologies of the 
Mediterranean Sea are the siliciclastic and the carbonate groups, representing $47 \%$ and $46 \%$ of the coastal area, respectively. The complex group represents $5 \%$ of the coastal area, while granitic and volcanic lithologies have a minimal contribution (1\% for each group).

For each lithological group, a value of $\mathrm{C}_{\mathrm{Sr}}$ and ${ }^{87} \mathrm{Sr} /{ }^{86} \mathrm{Sr}$ ratio of the groundwater could be assigned. These values are established mainly following Beck et al. (2013) (Table 3). For the granite, the volcanic and the complex aquifer type groups, the same values used for the calculation of SGD-driven Sr flux to the global ocean are used. For the siliciclastic group, average values of the shale and the sandstone categories are used. For the carbonate category, $\mathrm{C}_{\mathrm{Sr}}$ of $27-30 \mu \mathrm{M}$ and a respective $\mathrm{Sr}$ isotope ratio of $0.708020-0.707834$ can be derived on the base of the data reported in this work (see Section 4.2). Compared to the values reported by Beck et al. (2013) for the carbonate end-member $\left(\mathrm{C}_{\mathrm{Sr}}\right.$ of $10 \mu \mathrm{M}$ and ${ }^{87} \mathrm{Sr} /{ }^{86} \mathrm{Sr}$ of 0.708$)$, the measured $\mathrm{C}_{\mathrm{Sr}}$ is up to 3 times higher. Since this difference is high, we use a range of $10-30 \mu \mathrm{M}$ as representative of the $\mathrm{C}_{\mathrm{Sr}}$ of the carbonate SGD end-member in the calculation of the SGD-driven Sr flux to the entire Mediterranean Sea (Table 3).

For each SGD region delineated by Zektser et al. (2007), the average area and the concentration-weighted SGD end-member composition (concentration and isotope ratio) were calculated (Appendix A and B). The global SGD-driven Sr flux to the Mediterranean Sea is determined by combining the fresh SGD flow rate and the $\mathrm{C}_{\mathrm{Sr}}$ in the SGD end-member for each SGD region, while the Sr isotope ratio contribution is calculated for each region multiplying the SGD-driven Sr flux by the difference of ${ }^{87} \mathrm{Sr} /{ }^{86} \mathrm{Sr}$ between SGD and the Mediterranean seawater (Appendix A and B). A value of $(0.34-0.83) \cdot 10^{9} \mathrm{~mol} \mathrm{y}^{-1}$ is obtained for the Sr flux driven by SGD to the entire Mediterranean Sea, with an average discharge and concentration-weighted SGD end- 
member composition of $(5.0-12) \mu \mathrm{M}$ for the $\mathrm{Sr}$ and $(0.7086-0.7081)$ for the ${ }^{87} \mathrm{Sr} /{ }^{86} \mathrm{Sr}$ ratio. This flux represents $5-6 \%$ of the Sr flux obtained for the global ocean (Beck et al. 2013). Considering a coastline of $64 \cdot 10^{3} \mathrm{~km}$ (Stewart and Morhange 2009), a shorenormalized value of $(5.3-13) \cdot 10^{3} \mathrm{~mol} \mathrm{y}^{-1} \mathrm{~km}^{-1}$ is obtained for the $\mathrm{Sr}$ flux to the Mediterranean Sea. Whereas the shore-normalized fresh SGD flow rate in the Mediterranean Sea is 5 times lower than that in the global ocean, the shore normalized fresh SGD Sr flux to the Mediterranean Sea is only 2-3 times lower than the global ocean one. The SGD-driven Sr flux to the Mediterranean Sea associated with carbonate aquifers is $46-50 \%$ (Table 3) and the SGD end-member for the Mediterranean Sea is distinctly different from the SGD end-member of the global ocean, which is characterized by lower $\mathrm{C}_{\mathrm{Sr}}(2.9 \mu \mathrm{M})$ and higher ${ }^{87} \mathrm{Sr} /{ }^{86} \mathrm{Sr}$ ratio (0.7089) (Beck et al. 2013). Thus, the results demonstrated the significance of the carbonate end-member with respect to the others in the SGD contribution of Sr to seawater, as carbonates contain high concentration of $\mathrm{Sr}$ (exchangeable ion of $\mathrm{Ca}$ ) and are easily dissolved by groundwater.

A non-conservative mixing of $\mathrm{Sr}$ isotopes has been reported in several subterranean estuaries corresponding to a wide range of lithologies, despite a conservative trend of Sr concentrations with salinity (Beck et al. 2013). Thus, it is possible that some subterranean estuaries in the Mediterranean basin show this nonconservative behaviour for $\mathrm{Sr}$ isotopes, contrary to the three studied estuaries. Although the saline component of SGD does not represent a net Sr flux, since a significant portion of $\mathrm{Sr}$ in brackish SGD is derived from the recirculated seawater itself (see Section 4.2), geochemical reactions in the fresh/saline interface of the subterranean estuaries may alter the ${ }^{87} \mathrm{Sr} /{ }^{86} \mathrm{Sr}$ ratio of groundwater discharging to the Mediterranean Sea. Therefore, additional studies on the behaviour of Sr isotopes in subterranean estuaries of the 
Mediterranean Sea are needed in order to estimate the possible contribution of the brackish SGD component to the SGD-driven Sr flux.

\subsection{Sr fluxes into the Mediterranean Sea}

The fresh SGD-driven Sr flux to the Mediterranean Sea calculated in Section 4.3 can be compared to other sources of $\mathrm{Sr}$ of the basin. The main continental sources of $\mathrm{Sr}$ to seawater in the Mediterranean Sea are expected to be riverine discharge and also atmospheric dust deposition, because of the proximity to the Saharan desert.

For the input of Sr through rivers, the estimation by Peucker-Ehrenbrink et al. (2010), based on the geology of the drainage basin, yields a riverine dissolved $\mathrm{Sr}$ flux to the Mediterranean Sea of $1.6 \cdot 10^{9} \mathrm{~mol} \mathrm{y}^{-1}$ and a ${ }^{87} \mathrm{Sr} /{ }^{86} \mathrm{Sr}$ ratio of the river end-member of 0.7077 . Contrary to the global ocean, rivers are thus a source of less radiogenic Sr to seawater in this area. Compared to the riverine $\mathrm{Sr}$ flux, the input of $\mathrm{Sr}$ through fresh SGD, calculated in Section 4.3, is about 20 to $50 \%$ of it (Table 4), which is comparable to the result obtained for the global ocean by Beck et al. (2013).

For the atmospheric dust deposition, an approximate $\mathrm{Sr}$ input can be calculated by assuming that the continental crust has an average $\mathrm{Sr}$ concentration of $320 \mathrm{ng} \mathrm{mg}^{-1}$ (Hawkesworth and Kemp 2006) and around 65\% of this Sr is water-soluble in dust particles (Hsu et al. 2010). Considering atmospheric mass fluxes of $8-35 \mathrm{~g} \mathrm{~m}^{-2} \mathrm{y}^{-1}$ for the Mediterranean basin (Guerzoni et al. 1999), a flux of water-soluble Sr of (48 210) $\cdot 10^{6} \mathrm{~mol} \mathrm{y}^{-1}$ is obtained. We attribute to this flux a Sr isotope ratio of 0.709763 0.712092, as reported by Aarons et al. (2013) for the water soluble fraction of Saharan dust. Thus, the atmospheric deposition is a source of $\mathrm{Sr}$ more radiogenic than seawater, 
when there is an influence of Saharan dust. Compared to this atmospheric Sr flux, the fresh SGD-driven Sr flux, calculated in Section 4.3, is significantly larger (Table 4).

Therefore, the comparison of the fresh SGD-driven Sr flux with riverine discharge and atmospheric deposition clearly shows that SGD is a relevant continental source of Sr to the Mediterranean Sea. However, at a basin scale the most important source of $\mathrm{Sr}$ to the Mediterranean Sea is the inflow of Atlantic water through the Strait of Gibraltar. Considering a flow rate of $25.5 \cdot 10^{12} \mathrm{~m}^{3} \mathrm{y}^{-1}$ (Soto-Navarro et al. 2010) and a $\mathrm{C}_{\mathrm{Sr}}$ of 90 $\mu \mathrm{M}$, as measured in sample SW4, the Sr flux into the Mediterranean Sea through the Gibraltar Strait is $2.3 \cdot 10^{12} \mathrm{~mol} \mathrm{y}^{-1}$. This flux is 3 orders of magnitude higher than the sum of the continental inputs of Sr to the basin (Table 4). Thus, considering also the high residence time of $\mathrm{Sr}$ in seawater (>2.5 My) (Broecker and Peng 1982), it is clear that any influence of the SGD-driven inputs and the other continental sources of $\mathrm{Sr}$ cannot be noticed in the $\mathrm{Sr}$ isotope ratio of the Mediterranean seawater (the ${ }^{87} \mathrm{Sr} /{ }^{86} \mathrm{Sr}$ ratio of the Atlantic inflow (SW4) is identical to that measured for the Mediterranean Sea (SW3)). Nevertheless, the contribution of Sr to seawater from SGD (or from the other continental inputs) in the Mediterranean Sea can be registered in the nonconservative relation between $\mathrm{Sr}$ concentration and salinity in coastal seawater, confirming that SGD should be considered as an important source of Sr to the Mediterranean Sea.

\section{Conclusion}

The input of Sr to seawater through SGD was investigated in three subterranean estuaries of the Western Mediterranean Sea dominated by carbonate matrix.

Concentrations of $\mathrm{Sr}$ and ${ }^{87} \mathrm{Sr} /{ }^{86} \mathrm{Sr}$ ratios showed conservative mixing patterns in these subterranean estuaries, in contrast with the behaviour of $\mathrm{Sr}$ isotopes reported in the 
literature for similar aquifer lithologies. This reveals that $\mathrm{Sr}$ isotopes do not have a unique mixing behaviour, even in a given aquifer type.

The input of Sr to the entire Mediterranean Sea through SGD was also assessed, obtaining a value of $(0.34-0.83) \cdot 10^{9} \mathrm{~mol} \mathrm{y}^{-1}$ for the fresh SGD-driven $\mathrm{Sr}$ flux, which represents the $5-6 \%$ of the $\mathrm{Sr}$ flux to the global ocean. SGD is thus a source of less radiogenic Sr for the Mediterranean Sea. The Sr concentration of the global SGD endmember for the Mediterranean Sea $(5.0-12 \mu \mathrm{M})$ is higher than for the global ocean, while the ${ }^{87} \mathrm{Sr} /{ }^{86} \mathrm{Sr}$ ratio is lower $(0.7086-0.7081)$. This highlights the significance of carbonates as a source of Sr to groundwater discharging into the Mediterranean Sea. The fresh SGD Sr flux to the Mediterranean Sea is about $20-50 \%$ of the riverine flux and significantly higher than the atmospheric flux, so that SGD should be considered as a relevant continental source of $\mathrm{Sr}$ to the basin.

\section{ACKNOWLEDGMENTS}

We are grateful to Hans Schöberg and Karin Wallner for the great help with the analyses of the samples. We also thank our colleagues at the Laboratori de Radioactivitat Ambiental (Universitat Autònoma de Barcelona) and the crew of the B/O Ángeles Alvariño (Geotraces-GA04 - Medsea Cruise) for their help with the sampling activity. This project has been partially funded by the European Union Seventh Framework Programme through the MetTrans Initial Training Network, Marie Curie Actions, which also provide financial support through a PhD fellowship to GT (EU FP7-People-2011-ITN-290336). Support provided by the Generalitat de Catalunya to MERS (2014 SGR - 1356) is also acknowledged. VR acknowledges financial support from the European Union's FP7 (Marie Curie Actions PCOFUND-GA-2013-609102), through the PRESTIGE programme coordinated by Campus France. The Spanish Government (MINECO) is acknowledged for support to EGS through a post-doctoral grant (FPDI-2013-15660) and support of ECOALFACS project (CTM2009-09581) to the ICM-CSIC. PSA acknowledges support from the Swedish Research Council (VR 349-2012-6287). This research is also a contribution to the ANR @ RAction chair (ANR-14-ACHN-0007-01) and Labex OT-Med (ANR-11-LABEX-0061) funded by the "Investissements d'Avenir" program through the A*MIDEX project (ANR-11-IDEX0001-02) of the French National Research Agency (ANR). 
Aarons, S. M., S. M. Aciego, and J. D. Gleason. 2013. Variable HfSrNd radiogenic isotopic compositions in a Saharan dust storm over the Atlantic: Implications for dust flux to oceans, ice sheets and the terrestrial biosphere. Chem. Geol. 349-350: 18-26.

Albarède, F., A. Michard, J. F. Minster, and G. Michard. 1981. 87Sr/86Sr ratios in hydrothermal waters and deposits from the East Pacific Rise at $21^{\circ} \mathrm{N}$. Earth Planet. Sci. Lett. 55: 229-236.

Allègre, C. J., P. Louvat, J. Gaillardet, L. Meynadier, S. Rad, and F. Capmas. 2010. The fundamental role of island arc weathering in the oceanic Sr isotope budget. Earth Planet. Sci. Lett. 292: 51-56.

Amiotte Suchet, P., J.-L. Probst, and W. Ludwig. 2003. Worldwide distribution of continental rock lithology: Implications for the atmospheric/soil CO2 uptake by continental weathering and alkalinity river transport to the oceans. Global Biogeochem. Cycles 17: 1038.

Andersson, P. S., G. J. Wasserburg, and J. Ingri. 1992. The sources and transport of Sr and Nd isotopes in the Baltic Sea. Earth Planet. Sci. Lett. 113: 459-472.

Basu, A. R., S. B. Jacobsen, R. J. Poreda, C. B. Dowling, and P. K. Aggarwal. 2001. Large Groundwater Strontium Flux to the Oceans from the Bengal Basin and the Marine Strontium Isotope Record. Science (80-. ). 293: 1470-1473.

Bayó, A., C. Loaso, J. M. Aragonés, and E. Custodio. 1993. Marine intrusion and brackish water in coastal aquifers of Southern catalonia nad Castelló (Spain): a brief survey of actual problems and circumstances. Study and Modelling of Saltwater Intrusion into Aquifers, CIMNE, Barcelona. 229-243.

Beck, A. J., M. A. Charette, J. K. Cochran, M. E. Gonneea, and B. Peucker-Ehrenbrink. 2013. Dissolved strontium in the subterranean estuary - Implications for the marine strontium isotope budget. Geochim. Cosmochim. Acta 117: 33-52.

Broecker, W. S., and T. H. Peng. 1982. Tracers in the sea, Eldigio Press, LamontDoherty Geological Observatory, New York.

Burke, W. H., R. E. Denison, E. A. Hetherington, R. B. Koepnick, H. F. Nelson, and J. B. Otto. 1982. Variation of seawater $87 \mathrm{Sr} / 86 \mathrm{Sr}$ throughout Phanerozoic time. Geology 10: 516-519.

Burnett, W. C., H. Bokuniewicz, M. Huettel, W. S. Moore, and M. Taniguchi. 2003. Groundwater and pore water inputs to the coastal zone. Biogeochemistry 66: 3-33.

Cai, W. J., Y. Wang, J. Krest, and W. S. Moore. 2003. The geochemistry of dissolved inorganic carbon in a surficial groundwater aquifer in North Inlet, South Carolina, and the Carbon fluxes to the coastal ocean. Geochim. Cosmochim. Acta 67: 631-637. 
Camp, J., and M. Delgado. 1987. Hidrografia de las bahías del delta del Ebro. Investig. Pesq. 51: 351-369.

Davis, A. C., M. J. Bickle, and D. A. H. Teagle. 2003. Imbalance in the oceanic strontium budget. Earth Planet. Sci. Lett. 211: 173-187.

Delmonte, B., P. S. Andersson, M. Hansson, H. Schöberg, J. R. Petit, I. Basile-Doelsch, and V. Maggi. 2008. Aeolian dust in East Antarctica (EPICA-Dome C and Vostok): Provenance during glacial ages over the last 800 kyr. Geophys. Res. Lett. 35: 2-7.

Dürr, H. H., M. Meybeck, and S. H. Dürr. 2005. Lithologic composition of the Earth's continental surfaces derived from a new digital map emphasizing riverine material transfer. Global Biogeochem. Cycles 19, doi:10.1029/2005GB002515

Flecker, R., S. De Villiers, and R. M. Ellam. 2002. Modelling the effect of evaporation on the salinity-87Sr/86Sr relationship in modern and ancient marginalmarine systems: The Mediterranean Messinian Salinity Crisis. Earth Planet. Sci. Lett. 203: 221-233.

Garcia-Solsona, E., J. Garcia-Orellana, P. Masqué, V. Rodellas, M. Mejías, B. Ballesteros, and J. a. Domínguez. 2010. Groundwater and nutrient discharge through karstic coastal springs (Castelló, Spain). Biogeosciences 7: 26252638.

Guerzoni, S., R. Chester, F. Dulac, B. Herut, M. D. Loÿe-Pilot, C. Measures, C. Migon, E. Molinaroli, C. Moulin, P. Rossini, C. Saydam, A. Soudine, and P. Ziveri. 1999. The role of atmospheric deposition in the biogeochemistry of the Mediterranean Sea. Prog. Oceanogr. 44: 147-190.

Haley, B. a., M. Frank, R. F. Spielhagen, and J. Fietzke. 2008. Radiogenic isotope record of Arctic Ocean circulation and weathering inputs of the past 15 million years. Paleoceanography 23, doi:10.1029/2007PA001486

Hartmann, J., and N. Moosdorf. 2012. The new global lithological map database GLiM: A representation of rock properties at the Earth surface. Geochemistry, Geophys. Geosystems 13: 1-37.

Hawkesworth, C., and A. Kemp. 2006. Evolution of the continental crust. Nature 443: 811-817.

Hsu, S. C., G. T. F. Wong, G. C. Gong, F. K. Shiah, Y. T. Huang, S. J. Kao, F. Tsai, S. C. Candice Lung, F. J. Lin, I. I. Lin, C. C. Hung, and C. M. Tseng. 2010. Sources, solubility, and dry deposition of aerosol trace elements over the East China Sea. Mar. Chem. 120: 116-127.

Huang, K.-F., C.-F. You, C.-H. Chung, and I.-T. Lin. 2011. Nonhomogeneous seawater Sr isotopic composition in the coastal oceans: A novel tool for tracing water 
masses and submarine groundwater discharge. Geochemistry, Geophys. Geosystems 12: 1-14.

Instituto Geologico Minero de España (IGME). 1986. Mapa del Karst de España.

Johannesson, K. H., D. A. Chevis, D. J. Burdige, J. E. Cable, J. B. Martin, and M. Roy. 2011. Submarine groundwater discharge is an important net source of light and middle REEs to coastal waters of the Indian River Lagoon, Florida, USA. Geochim. Cosmochim. Acta 75: 825-843.

Jones, M. T., S. R. Gislason, K. W. Burton, C. R. Pearce, V. Mavromatis, P. a. E. Pogge von Strandmann, and E. H. Oelkers. 2014. Quantifying the impact of riverine particulate dissolution in seawater on ocean chemistry. Earth Planet. Sci. Lett. 395: 91-100.

Jones, M. T., C. R. Pearce, C. Jeandel, S. R. Gislason, E. S. Eiriksdottir, V. Mavromatis, and E. H. Oelkers. 2012. Riverine particulate material dissolution as a significant flux of strontium to the oceans. Earth Planet. Sci. Lett. 355-356: 51-59.

Llebot, C., F. J. Rueda, J. Solé, M. L. Artigas, and M. Estrada. 2014. Hydrodynamic states in a wind-driven microtidal estuary (Alfacs Bay). J. Sea Res. 85: 263276.

Ludwig, W., E. Dumont, M. Meybeck, and S. Heussner. 2009. River discharges of water and nutrients to the Mediterranean and Black Sea: Major drivers for ecosystem changes during past and future decades? Prog. Oceanogr. 80: 199217.

Martin, J. B., and P. J. Moore. 2008. Sr concentrations and isotope ratios as tracers of ground-water circulation in carbonate platforms: Examples from San Salvador Island and Long Island, Bahamas. Chem. Geol. 249: 52-65.

McNutt, R. H. 2000. Environmental Tracers in Subsurface Hydrology, p. 233-260. In P.G. Cook and A.L. Herczeg [eds.], Environmental Tracers in Subsurface Hydrology. Springer US.

Mejías, M., B. J. Ballesteros, C. Antón-Pacheco, J. a. Domínguez, J. Garcia-Orellana, E. Garcia-Solsona, and P. Masqué. 2012. Methodological study of submarine groundwater discharge from a karstic aquifer in the Western Mediterranean Sea. J. Hydrol. 464-465: 27-40.

Mejías, M., J. Garcia-Orellana, J. L. Plata, M. Marina, E. Garcia-Solsona, B. Ballesteros, P. Masqué, J. López, and C. Fernández-Arrojo. 2008. Methodology of hydrogeological characterization of deep carbonate aquifers as potential reservoirs of groundwater. Case of study: The Jurassic aquifer of El Maestrazgo (Castellón, Spain). Environ. Geol. 54: 521-536. 
Moore, W. S. 1996. Large groundwater inputs to coastal water revealed by $226 \mathrm{Ra}$ enrichments. Nature 380: 612-614.

Palmer, M. R., and J. M. Edmond. 1989. The strontium isotope budget of the modern ocean. Earth Planet. Sci. Lett. 92: 11-26.

Peucker-Ehrenbrink, B., M. W. Miller, T. Arsouze, and C. Jeandel. 2010. Continental bedrock and riverine fluxes of strontium and neodymium isotopes to the oceans. Geochemistry, Geophys. Geosystems 11, doi:10.1029/2009GC002869

Rahaman, W., and S. K. Singh. 2012. Sr and 87Sr/86Sr in estuaries of western India: Impact of submarine groundwater discharge. Geochim. Cosmochim. Acta 85: 275-288.

Rodellas, V., J. Garcia-Orellana, E. Garcia-Solsona, P. Masqué, J. A. Domínguez, B. J. Ballesteros, M. Mejías, and M. Zarroca. 2012. Quantifying groundwater discharge from different sources into a Mediterranean wetland by using 222Rn and Ra isotopes. J. Hydrol. 466-467: 11-22.

Rodellas, V., J. Garcia-Orellana, P. Masqué, M. Feldman, and Y. Weinstein. 2015. Submarine groundwater discharge as a major source of nutrients to the Mediterranean Sea. Proc. Natl. Acad. Sci. U. S. A. 112: 3926-30.

Rodellas, V., J. Garcia-Orellana, G. Trezzi, P. Masqué, T. C. Stieglitz, H. Bokuniewicz, J. Kirk Cochran, and E. Berdalet. 2017. Using the radium quartet to quantify submarine groundwater discharge and porewater exchange. Geochim. Cosmochim. Acta 196: 58-73.

Slomp, C. P., and P. Van Cappellen. 2004. Nutrient inputs to the coastal ocean through submarine groundwater discharge: Controls and potential impact. J. Hydrol. 295: 64-86.

Soto-Navarro, J., F. Criado-Aldeanueva, J. García-Lafuente, and A. Sánchez-Román. 2010. Estimation of the Atlantic inflow through the Strait of Gibraltar from climatological and in situ data. J. Geophys. Res. 115: C10023.

Stewart, I., and C. Morhange. 2009. The Physical Geography of the Mediterranean,.

Topper, R. P. M., R. Flecker, P. T. Meijer, and M. J. R. Wortel. 2011. A box model of the Late Miocene Mediterranean Sea: Implications from combined $87 \mathrm{Sr} / 86$ Sr and salinity data. Paleoceanography 26, doi:10.1029/2010PA002063

Tovar-Sánchez, A. 2012. Sampling approches for trace element determination in seawater, p. 317-334. In J. Pawliszyn and J.M. Bayona [eds.], Comprehensive Sampling and Sample Preparation. Academic Press: Oxford, UK.

Tovar-Sánchez, A., G. Basterretxea, V. Rodellas, D. Sánchez-Quiles, J. GarciaOrellana, P. Masqué, A. Jordi, J. M. López, and E. Garcia-Solsona. 2014. Contribution of Groundwater Discharge to the Coastal Dissolved Nutrients 
and Trace Metal Concentrations in Majorca Island: Karstic vs Detrital Systems. Environ. Sci. Technol. 48: 11819-11827.

Trezzi, G., J. Garcia-Orellana, V. Rodellas, J. Santos-Echeandia, A. Tovar-Sánchez, E. Garcia-Solsona, and P. Masqué. 2016a. Submarine groundwater discharge: A significant source of dissolved trace metals to the North Western Mediterranean Sea. Mar. Chem. 186: 90-100.

Trezzi, G., J. Garcia-Orellana, J. Santos-Echeandia, V. Rodellas, E. Garcia-Solsona, G. Garcia-Fernandez, and P. Masqué. 2016b. The influence of a metal-enriched mining waste deposit on submarine groundwater discharge to the coastal sea. Mar. Chem. 178: 35-45.

Windom, H. L., W. S. Moore, L. F. H. Niencheski, and R. a. Jahnke. 2006. Submarine groundwater discharge: A large, previously unrecognized source of dissolved iron to the South Atlantic Ocean. Mar. Chem. 102: 252-266.

Zarroca, M., R. Linares, V. Rodellas, J. Garcia-Orellana, C. Roqué, J. Bach, and P. Masqué. 2014. Delineating coastal groundwater discharge processes in a wetland area by means of electrical resistivity imaging, 224Ra and 222Rn. Hydrol. Process. 28: 2382-2395.

Zektser, I. S., R. G. Dzhamalov, and L. G. Everett. 2007. Submarine Groundwater, L.G. Everett [ed.]. CRC Press. 


\section{Table 1}

Sr concentrations $\left(\mathrm{C}_{\mathrm{Sr}}\right)$, Sr isotope ratio and salinity of water samples. Both internal and external precisions of ${ }^{87} \mathrm{Sr} /{ }^{86} \mathrm{Sr}$ ratios are reported.

\begin{tabular}{|c|c|c|c|c|c|c|c|c|c|}
\hline Sample site & Sample ID & Sample type & $\begin{array}{c}\text { Depth } \\
\text { (m) }\end{array}$ & Salinity & $\begin{array}{l}\mathbf{S r} \\
(\mu \mathrm{M})\end{array}$ & $\begin{array}{l}\text { Error } \\
2 \sigma \mathrm{Sr} \\
(\mu \mathrm{M})\end{array}$ & ${ }^{87} \mathrm{Sr} /{ }^{86} \mathrm{Sr}$ & $\begin{array}{l}\text { Int. prec. } \\
2 \sigma \mathrm{m}^{87} \mathrm{Sr} /{ }^{86} \mathrm{Sr}\end{array}$ & $\begin{array}{l}\text { Ext. prec. } \\
{ }^{2 \sigma}{ }^{87} \mathrm{Sr} /{ }^{86} \mathrm{Sr}\end{array}$ \\
\hline \multirow[t]{4}{*}{ Irta Range } & W1 & Groundwater & n.r. & 0.3 & 6.04 & 0.03 & 0.707810 & 0.000005 & 0.000008 \\
\hline & KS1 & Groundwater & surf & 8.7 & 28.3 & 0.1 & 0.708953 & 0.000006 & 0.000008 \\
\hline & KS2 & Groundwater & surf & 5.8 & 19.0 & 0.1 & 0.708904 & 0.000005 & 0.000008 \\
\hline & KS3 & Groundwater & surf & 7.1 & 23.2 & 0.1 & 0.708981 & 0.000005 & 0.000008 \\
\hline \multirow[t]{14}{*}{ Peníscola wetland } & S1LL & Groundwater & 60 & 20.3 & 167 & 0.8 & 0.708471 & 0.000005 & 0.000008 \\
\hline & S1C & Groundwater & 25 & 19.4 & 167 & 0.8 & 0.708471 & 0.000004 & 0.000008 \\
\hline & S2LL & Groundwater & 16 & 17.6 & 154 & 0.8 & 0.708459 & 0.000006 & 0.000008 \\
\hline & $\mathbf{S 2 C}$ & Groundwater & 12 & 10.6 & 96.7 & 0.5 & 0.708455 & 0.000005 & 0.000008 \\
\hline & S3 & Groundwater & 4 & 15.1 & 118 & 0.6 & 0.708385 & 0.000005 & 0.000008 \\
\hline & ST7 & Groundwater & surf & 0.9 & 13.7 & 0.1 & 0.707947 & 0.000008 & 0.000008 \\
\hline & ST32S & Groundwater & surf & 3.3 & 31.9 & 0.2 & 0.708300 & 0.000005 & 0.000008 \\
\hline & ST32M & Groundwater & 0.4 & 6.9 & 57.9 & 0.3 & 0.708411 & 0.000005 & 0.000008 \\
\hline & ST32D & Groundwater & 0.9 & 13.0 & 107 & 0.5 & 0.708473 & 0.000005 & 0.000008 \\
\hline & ST47 & Groundwater & surf & 5.3 & 46.5 & 0.2 & 0.708388 & 0.000004 & 0.000008 \\
\hline & $\mathbf{P 1}$ & Groundwater & surf & 8.4 & 70.6 & 0.4 & 0.708441 & 0.000005 & 0.000008 \\
\hline & $\mathbf{P 2}$ & Groundwater & surf & 6.7 & 57.0 & 0.3 & 0.708418 & 0.000005 & 0.000008 \\
\hline & W2 & Groundwater & n.r. & 0.5 & 7.76 & 0.04 & 0.707930 & 0.000005 & 0.000008 \\
\hline & SW1 & Seawater & surf & 37.1 & 92.5 & 0.5 & 0.709158 & 0.000005 & 0.000008 \\
\hline
\end{tabular}




\begin{tabular}{|c|c|c|c|c|c|c|c|c|c|}
\hline \multirow[t]{10}{*}{ Ebro Delta } & ER & River & surf & 0.7 & 22.2 & 0.1 & 0.708547 & 0.000006 & 0.000008 \\
\hline & $\mathrm{C1}$ & Channel & surf & 0.9 & 19.4 & 0.1 & 0.708448 & 0.000004 & 0.000008 \\
\hline & $\mathrm{C} 2$ & Channel & surf & 10.7 & 36.8 & 0.2 & 0.708846 & 0.000005 & 0.000008 \\
\hline & $\mathrm{C3}$ & Channel & surf & 31.2 & 70.1 & 0.4 & 0.709090 & 0.000005 & 0.000008 \\
\hline & $\mathrm{C4}$ & Channel & surf & 1.3 & 18.3 & 0.1 & 0.708116 & 0.000005 & 0.000008 \\
\hline & KS4 & Groundwater & surf & 5.8 & 44.0 & 0.2 & 0.708108 & 0.000005 & 0.000008 \\
\hline & KS5 & Groundwater & surf & 4.2 & 47.3 & 0.2 & 0.707949 & 0.000005 & 0.000008 \\
\hline & W3 & Groundwater & n.r. & 2.2 & 30.0 & 0.1 & 0.707923 & 0.000005 & 0.000008 \\
\hline & P3 & Groundwater & surf & 1.3 & 12.2 & 0.1 & 0.708068 & 0.000007 & 0.000008 \\
\hline & SW2 & Seawater & surf & 34.9 & 89.4 & 0.5 & 0.709158 & 0.000004 & 0.000008 \\
\hline Catalano-Balearic Basin & SW3 & Seawater & surf & 38.3 & 95.2 & 0.5 & 0.709162 & 0.000005 & 0.000008 \\
\hline Atlantic inflow & SW4 & Seawater & surf & 36.3 & 90.4 & 0.5 & 0.709163 & 0.000004 & 0.000008 \\
\hline Mediterranean outflow & SW5 & Seawater & 500 & 38.5 & 95.8 & 0.5 & 0.709159 & 0.000006 & 0.000008 \\
\hline
\end{tabular}

n.r. $=$ not registered

Surf $=$ surface 
Table 2

SGD-driven Sr fluxes from the eastern coast of the Iberian Peninsula and comparison with the riverine input.

\begin{tabular}{|c|c|c|c|c|c|}
\hline \multirow[t]{2}{*}{ Study site } & \multicolumn{2}{|c|}{$\begin{array}{l}\text { Flow rates } \\
\left(10^{3} \mathrm{~m}^{3} \mathrm{~d}^{-1}\right)\end{array}$} & \multicolumn{2}{|c|}{ Fresh end-members } & \multirow[t]{2}{*}{$\begin{array}{l}\text { Net Sr flux } \\
\left(10^{3} \mathrm{~mol} \mathrm{~d}^{-1}\right)\end{array}$} \\
\hline & $\begin{array}{c}\text { Brackish } \\
\text { SGD }\end{array}$ & Fresh SGD & $\begin{array}{c}\mathbf{S r} \\
(\mu \mathrm{M})\end{array}$ & ${ }^{87} \mathrm{Sr} /{ }^{86} \mathrm{Sr}$ & \\
\hline Irta Range & $72-190^{\mathrm{a}}$ & $51-160$ & 6.0 & 0.707810 & $0.31-0.96$ \\
\hline Peníscola & $34-83^{b}$ & $34-83$ & 46 & 0.708388 & $1.6-3.9$ \\
\hline Ebro delta & $40-310^{c}$ & $35-270$ & 38 & 0.707604 & $1.3-10$ \\
\hline \multirow[t]{2}{*}{ E Iberian Peninsula } & & & $27-30$ & $0.708020-0.707834$ & \\
\hline & \multicolumn{2}{|c|}{ Rivers (Ebro River) } & & & \\
\hline E Iberian Peninsula & \multicolumn{2}{|c|}{$36000^{\mathrm{d}}$} & 22 & 0.70852 & 800 \\
\hline
\end{tabular}

\footnotetext{
${ }^{\mathrm{a}}$ Garcia-Solsona et al. (2010)

${ }^{\mathrm{b}}$ Rodellas et al. (2012)

${ }^{\mathrm{c}}$ Rodellas et al. (2017)

${ }^{\mathrm{d}}$ Ludwig et al. (2009).
} 


\section{Table 3}

Sr concentration of groundwater in aquifers of different lithology and the contribution of each lithology to the Sr flux into the Mediterranean Sea. The carbonate group includes only sedimentary carbonate rocks; the siliciclastic group is composed of sedimentary rocks dominated by silica-rich minerals and unconsolidated sediments, characterized by the absence of carbonate minerals; the granite group mainly consists of acid plutonic rocks, with a minor contribution of acid volcanic rocks; the volcanic group is composed principally by basic and intermediate volcanic rocks and secondly by basic plutonic rocks; the complex group includes sedimentary mixed rocks (both siliciclastic and carbonate rocks, which could not be separate at the map scale) and metamorphic rocks, for which it is difficult to establish the percentage of carbonate and silicate minerals.

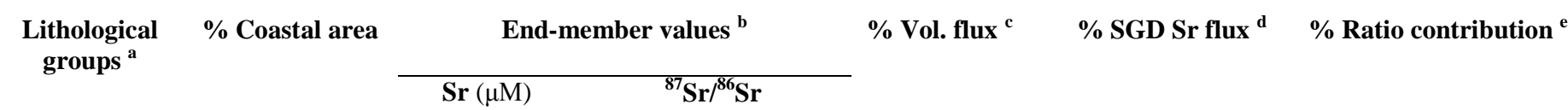

\begin{tabular}{lcccccc} 
Carbonate & 46 & $10-30$ & $0.708020-0.707834$ & 36 & $46-50$ & $56-65$ \\
Siliciclastic & 47 & 2.5 & 0.7105 & 43 & $36-39$ & 1 \\
Granite & 1 & 0.5 & 0.713 & 3 & 1 & 1 \\
Volcanic & 1 & 2 & 0.706 & 2 & $12-13$ & $10-11$ \\
Complex & 5 & 2 & 0.709 & 16 & 12 \\
\hline
\end{tabular}

\footnotetext{
${ }^{a}$ Lithological groups are estimated starting from the GLIM database geological map (Hartmann and Moosdorf, 2012).

${ }^{\mathbf{b}}$ End-members values of $\mathrm{Sr}$ concentration and ${ }^{87} \mathrm{Sr} /{ }^{86} \mathrm{Sr}$ are estimated following Beck et al., 2013 and employing Sr data of this study for the carbonate group.

$\mathbf{c}_{\mathbf{c}, \mathbf{d}, \mathbf{e}}$ Fluxes calculated as explained in Appendix C
} 


\section{Table 4}

Characterization of different sources of Sr to the Mediterranean Sea

\begin{tabular}{cccc}
\hline Source & $\begin{array}{c}\text { Sr } \\
(\mu \mathrm{M})\end{array}$ & ${ }^{87} \mathbf{S r} /{ }^{86} \mathbf{S r}$ & $\begin{array}{c}\text { Sr flux } \\
\left(10^{6} \mathrm{~mol} \mathrm{y}^{-1}\right)\end{array}$ \\
\hline Meteoric SGD & $5.0-12$ & $0.7081-0.7086$ & $340-830$ \\
Rivers $^{\text {a }}$ & 4.0 & 0.7077 & 1600 \\
Atmospheric deposition $^{\text {b }}$ & & $0.709763-0.712092$ & $47-210$ \\
Atlantic Ocean inflow $^{c}$ & 90 & 0.70916 & $2.3 \cdot 10^{6}$ \\
\hline
\end{tabular}

\footnotetext{
${ }^{\text {a }}$ Peucker-Ehrenbrink et al., 2010

${ }^{\mathbf{b}}$ Calculated with data from Hawkesworth and Kemp (2006), Hsu et al. (2010), Guerzoni et al. (1999), Aarons et al. (2013)

${ }^{\mathbf{c}}$ Calculated with data from Soto-Navarro et al. (2010), Broecker and Peng (1982) and this study.
} 


\section{Figure 1}

a) Location of the areas of study in the Western Mediterranean Sea and of the seawater samples collected during the Geotraces-GA04 - MedSea cruise. b) c) d) Sampling stations in the Irta Mountain area, in the Peníscola wetland and in the Ebro delta zone, respectively. Sample W2 of the Peníscola wetland is out of scale in map b) but it is represented in map a).

\section{Figure 2}

Sr concentrations vs salinity in the analysed seawater samples. Dotted lines represent the conservative behaviour of Sr.

\section{Figure 3}

Irta Range area: a) $\mathrm{C}_{\mathrm{Sr}}$ vs salinity; b) ${ }^{87} \mathrm{Sr} /{ }^{86} \mathrm{Sr}$ ratio vs $1 / \mathrm{C}_{\mathrm{Sr}}$. Black circles indicate water end-members of the system (well W1 and seawater SW3), while white triangles are the karstic spring samples (KS1, KS2, KS3). Dotted lines represent the conservative mixing behaviour. Error bars of $\mathrm{C}_{\mathrm{Sr}}$ and of $\mathrm{Sr}$ isotope ratios are smaller than the symbol size.

\section{Figure 4}

Peníscola wetland: a) $\mathrm{C}_{\mathrm{Sr}}$ vs salinity; b) ${ }^{87} \mathrm{Sr} /{ }^{86} \mathrm{Sr}$ ratio vs $1 / \mathrm{C}_{\mathrm{Sr}}$. Black circles indicate water end-members of the system (channel ST7, piezometer S1LL, well W1, seawater SW1 and SW3). White triangles are the other groundwater samples of the marsh (piezometers S1C, S2LL, S2C and S3, channel ST32S, ST32M and ST32D, ponds P1 and P2). The grey diamond is the outlet of the marsh into the sea (ST47). Dotted lines 
represent the conservative mixing behaviour. Error bars of $\mathrm{C}_{\mathrm{Sr}}$ and of $\mathrm{Sr}$ isotope ratios are smaller than the symbol size.

\section{Figure 5}

Ebro delta area: a) $\mathrm{C}_{\mathrm{Sr}}$ vs salinity; b) ${ }^{87} \mathrm{Sr} /{ }^{86} \mathrm{Sr}$ ratio vs $1 / \mathrm{C}_{\mathrm{Sr}}$. Black circles indicate water end-members of the system (Ebro River ER, pond P3, seawater SW2 and SW3), while white triangles are the karstic springs (KS4, KS5), the irrigation channels $(\mathrm{C} 1$, $\mathrm{C} 2, \mathrm{C} 3, \mathrm{C} 4)$ and the well W3. Dotted lines represent the conservative mixing behaviours. Error bars of $\mathrm{C}_{\mathrm{Sr}}$ and of $\mathrm{Sr}$ isotope ratios are smaller than the symbol size. 


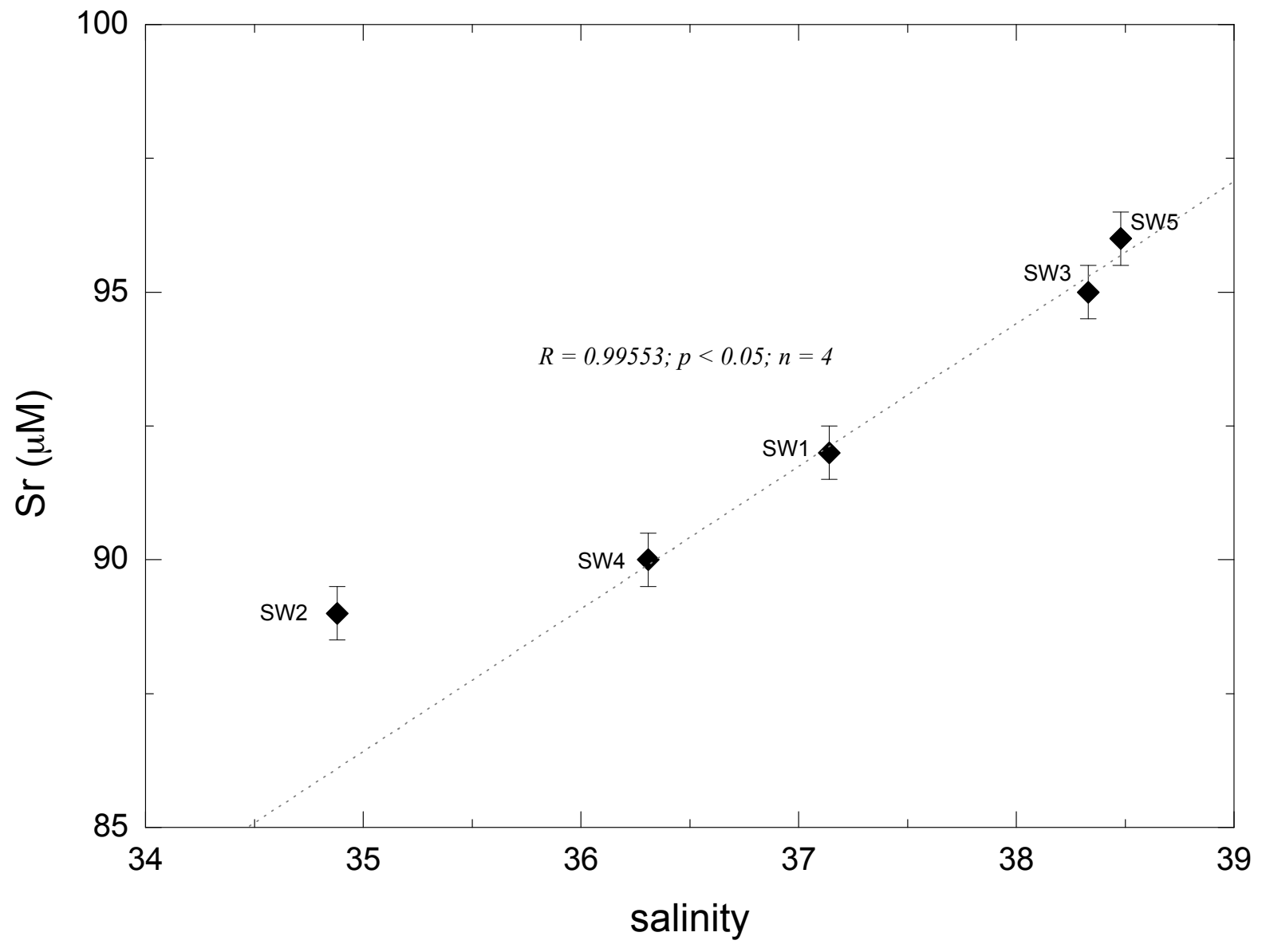



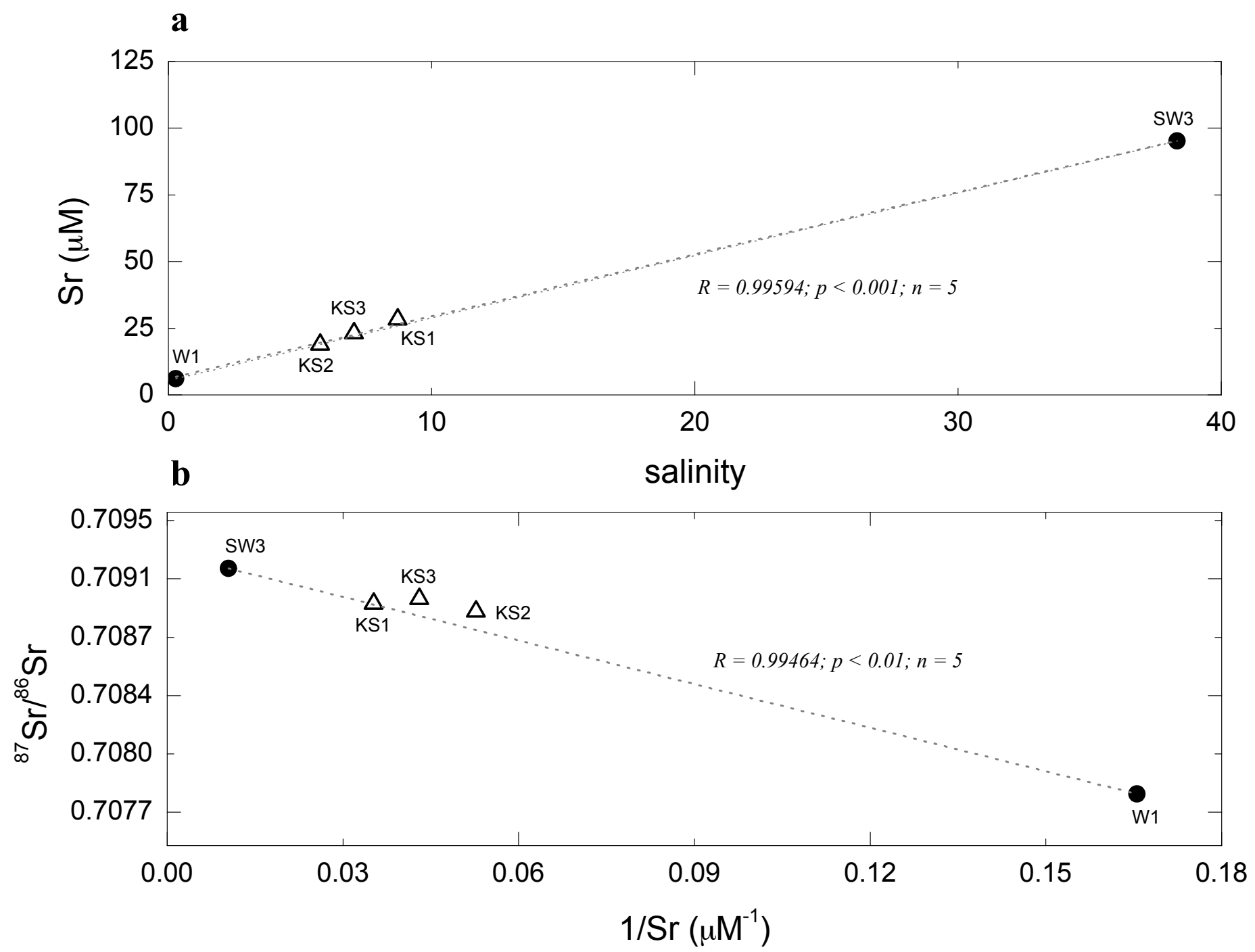

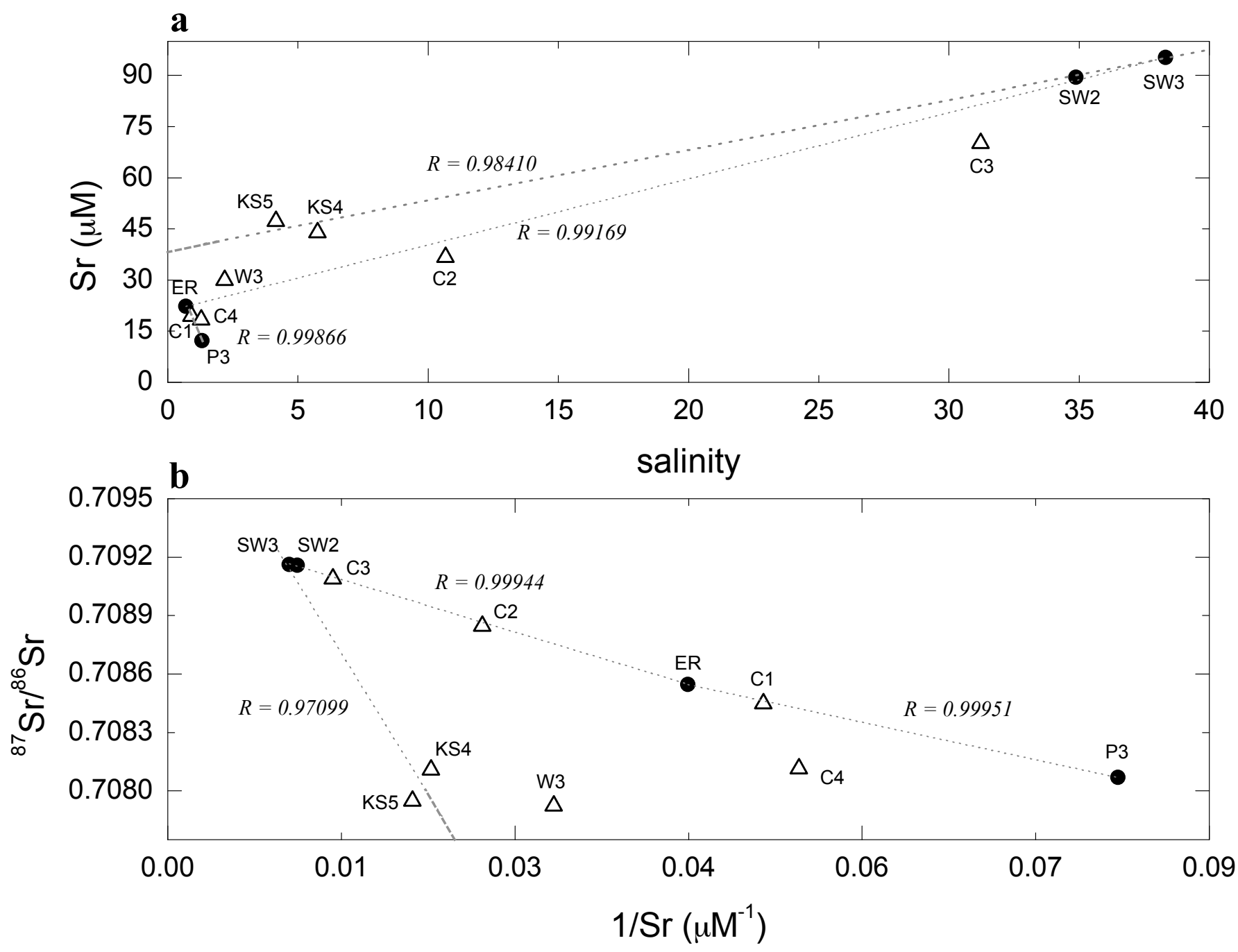


\section{Appendix A}

Calculations of SGD-driven Sr fluxes in each SGD region of the Mediterranean Sea (results reported in Appendix B).

- Average-weighted Sr concentration of the SGD end-member:

$S r_{\text {reg }}=\frac{\sum\left(S r_{l i t h} \%{ }_{l i t h}\right)}{100}$

- Average-weighted ${ }^{87} \mathrm{Sr} /{ }^{86} \mathrm{Sr}$ concentration of the SGD end-member:

${ }^{87} \mathrm{Sr} /{ }^{86} \mathrm{Sr} r_{\text {reg }}=\frac{\sum\left(S r_{l i t h} \cdot{ }^{87} S r /{ }^{86} S r_{l i t h} \cdot \% \text { lith }\right)}{S r_{r e g}}$

- SGD-driven Sr flux:

$S G D$ Sr flux $_{\text {reg }}=S r_{\text {reg }} \cdot S G D$ flow $_{\text {reg }}$

SGD-driven Sr ratio flux:

$S G D$ Sr ratio flux $_{\text {reg }}=S r_{\text {reg }} \cdot S G D$ flow reg $\cdot{ }^{87} \mathrm{Sr} /{ }^{86} \mathrm{Sr}{ }_{\text {reg }}$

where $\mathrm{Sr}_{\text {lith }}$ and ${ }^{87} \mathrm{Sr} /{ }^{86} \mathrm{Sr}_{\text {lith }}$ are the $\mathrm{Sr}$ concentration and the ${ }^{87} \mathrm{Sr} /{ }^{86} \mathrm{Sr}$ ratio assigned to each lithological group, respectively, $\%$ lith is the relative percentage of each lithology in the SGD region and SGD flow reg $_{\text {is }}$ the SGD flow rate of the region as reported in Zektser et al. (2007). 


\section{Appendix B}

Table B.1 Contribution of each SGD region to the Sr flux into the Mediterranean Sea.

\begin{tabular}{|c|c|c|c|c|c|c|c|c|c|c|c|c|}
\hline SGD region & $\begin{array}{c}\text { Subsurface } \\
\text { drainage } \\
\text { area } \\
\left(10^{3} \mathrm{~km}^{2}\right)\end{array}$ & $\begin{array}{l}\text { SGD flow } \\
\text { rate } \\
\left(\mathrm{km}^{3} \mathrm{y}^{-1}\right)\end{array}$ & $\begin{array}{c}\% \text { of Med } \\
\text { SGD }\end{array}$ & $\begin{array}{c}\% \\
\text { carbonate }\end{array}$ & $\begin{array}{c}\% \\
\text { siliciclastic }\end{array}$ & $\begin{array}{c}\% \\
\text { granite }\end{array}$ & $\begin{array}{c}\% \\
\text { volcanic }\end{array}$ & $\begin{array}{c}\% \\
\text { complex }\end{array}$ & $\begin{array}{l}\mathbf{S r}^{\mathbf{a}} \\
(\mu \mathrm{M})\end{array}$ & ${ }^{87} \mathrm{Sr} /{ }^{86} \mathrm{Sr}^{\mathrm{b}}$ & $\begin{array}{c}\text { SGD Sr flux } \\
\left(10^{6} \mathrm{~mol} \mathrm{y}^{-1}\right)\end{array}$ & $\begin{array}{c}\text { Ratio } \\
\text { contribution }^{\mathrm{d}} \\
\left(10^{3}\right)\end{array}$ \\
\hline renean Peninsula & 44.5 & 2.37 & 3.5 & 5 & 55 & 5 & 0 & 35 & $3-4$ & $0.7096-0.7091$ & $6.2-8.5$ & $+(3.0-0.39)$ \\
\hline South of France & 24.4 & 4.88 & 7.2 & 25 & 65 & 0 & 0 & 10 & $4-9$ & $0.7090-0.7083$ & $21-46$ & $-(3.4-38)$ \\
\hline ennine Peninsula & 91.5 & 18.52 & 27 & 60 & 40 & 0 & 0 & 0 & $7-19$ & $0.7084-0.7080$ & $130-350$ & $-(100-420)$ \\
\hline mbardic lowlands & 16.0 & 3.2 & 4.6 & 0 & 100 & 0 & 0 & 0 & 3 & 0.7105 & 8.0 & +11 \\
\hline inara Mountains & 14.5 & 5.84 & 8.6 & 80 & 10 & 0 & 0 & 10 & $8-24$ & $0.7081-0.7079$ & $49-140$ & $-(51-180)$ \\
\hline alkan Peninsula & 78.5 & 13.84 & 20 & 25 & 30 & 0 & 0 & 45 & $4-9$ & $0.7087-0.7082$ & $57-130$ & $-(28-130)$ \\
\hline Lesser Asia & 74.0 & 6.9 & 10 & 15 & 40 & 0 & 10 & 35 & $3-6$ & $0.7088-0.7083$ & $24-44$ & $-(7.7-37)$ \\
\hline Near east & 34.1 & 1.42 & 2.1 & 35 & 55 & 0 & 5 & 5 & $5-12$ & $0.7087-0.7081$ & $7.2-17$ & $-(3.5-18)$ \\
\hline Lybian Desert & 318.4 & 1.59 & 2.3 & 55 & 45 & 0 & 0 & 0 & $7-18$ & $0.7084-0.7080$ & $11-28$ & $-(7.6-32)$ \\
\hline tlas Mountains & 85.4 & 3.49 & 5.2 & 5 & 95 & 0 & 0 & 0 & $3-4$ & $0.7101-0.7095$ & $10-14$ & $+(9.1-4.2)$ \\
\hline Sicily & 24.9 & 1.25 & 1.8 & 70 & 20 & 0 & 10 & 0 & $8-22$ & $0.7081-0.7079$ & $9.6-27$ & $-(9.9-35)$ \\
\hline Sardinia & 31.8 & 3.18 & 4.7 & 10 & 35 & 45 & 10 & 0 & $2-4$ & $0.7093-0.7086$ & $7.3-14$ & $-(0.8-8.2)$ \\
\hline Corsica & 8.4 & 1.27 & 1.9 & 0 & 10 & 65 & 0 & 25 & 1 & 0.7106 & 1.4 & +1.9 \\
\hline
\end{tabular}

$\mathbf{a , b , c , d}$ Calculated as expleined in Appendix A 


\section{Appendix C}

Calculation of SGD-driven Sr fluxes into the Mediterranean Sea from each aquifer type lithology (results reported in Table 3).

- $\quad$ Average-weighted SGD volume fluxes:

$\%$ volume $_{\text {flux }}$ lith $=\frac{\sum\left(\% \mathrm{lith}_{\mathrm{reg}} \text { SGD flow } \mathrm{reg}\right)}{\sum S G D \text { flow }_{\text {reg }}}$

- $\quad$ Average-weighted SGD-driven Sr flux:

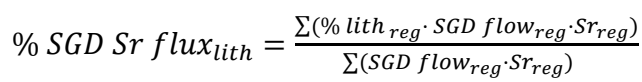

- $\quad$ Average-weighted SGD-driven Sr ratio flux:

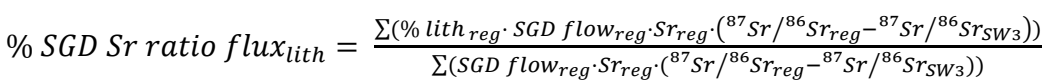

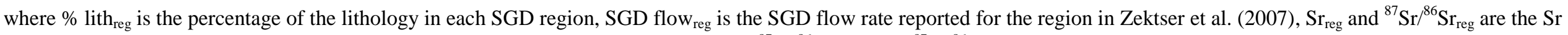
concentration and the Sr isotope ratio calculated for each SGD region, respectively and ${ }^{87} \mathrm{Sr}^{86} \mathrm{Sr}_{\mathrm{Sw}}$ is the ${ }^{87} \mathrm{Sr} /{ }^{86} \mathrm{Sr}$ ratio of the Mediterranean $\mathrm{Seawater}$. 